\title{
North-West Indian fauna of genus Macrobathra Meyrick (Lepidoptera : Gelechioidea : Cosmopterigidae)
}

\author{
Deepak WADHAWAN and Virinder Kumar WALIA * \\ Department of Zoology, Panjab University, Chandigarh - 160014, India \\ *Corresponding author, E-mail: virinder_k_walia@rediffmail.com
}

\begin{abstract}
Two first representative species of genus Macrobathra Meyrick viz., gentilis Meyrick and ochrefasciata sp. nov. are reported from three inadequately surveyed North-West Indian states, namely Haryana, Himachal Pradesh and Rajasthan. With the addition of another new species, total number of species under the aforementioned genus is enhanced to eight from India. The present communication deals with the structure of genitalia and salient morphological features of already known M. gentilis along with detailed account of $M$. ochrefasciata sp. nov. The text of both species is supported by relevant pictorial depictions.

(C) 2007 International Formulae Group. All rights reserved.
\end{abstract}

Keywords: Cosmopterigidae, Macrobathra, 2 species, new record, North-West India.

\section{INTRODUCTION}

Distribution of genus Macrobathra Meyrick ranges throughout the Afro-tropical and Indo-Australian regions, with a few species from Eastern Palearctic. Out of more than 130 species known so far under it, majority are Australian and only 12 from south-east Asia (Robinson et al., 1994), including 7 from India (Meyrick, 1922; Gaede, 1938; Clarke, 1963). Intensive and extensive surveys of different localities in Haryana, Himachal Pradesh and Rajasthan from March to October of 2000-2004 resulted in collection of 29 specimens of two species that were totally in agreement with all the characters of genus Macrobathra (Meyrick, 1922). Congeneric bonds of both species were further supported by not only visual similarities in general body colouration and wing maculation (Robinson et al., 1994) but also alike shape of significant parts of male and female genitalia. After consulting relevant literature, only one of the two species was identified as M. gentilis Meyrick whereas the other was adjudged as new addition to the existing fauna of referred genus (Meyrick, 1910, 1914a, 1914b, 1915, 1923-1930. 19301936; Clarke, 1963; Robinson et al., 1994).

\section{SYSTEMATIC ACCOUNT}

- Genus Macrobathra Meyrick

Macrobathra Meyrick, 1883, Proc. Linn. Soc. N.S. W., $7: 425$. Nomenclaturally available but without included nominal species until Meyrick, 1886, ibidem, $10: 800$.

Type-species: Macrobathra chrysotoxa Meyrick, 1886, Proc. Linn. Soc. N.S.W., 10 : 804 , by subsequent designation by Meyrick, 1922, in Wystman, Genera Insect., 180 : 17.

Key to species of the genus Macrobathra Meyrick:

1. Male genitalia with gnathos asymmetrical, its lobes curved inwards, without thorn-like structure, valvae equalsized, with one besides juxtal process without conical sclerotization; female genitalia with both signa equal-sized, similar shaped and closely lying...... gentilis Meyrick.

2. Male genitalia with gnathos symmetrical, lobes straight and parallel with 
thorn-like structure on outer margin of each, valvae unequal, with one adjoining juxtal process extended into strongly sclerotized conical process towards it; female genitalia with signa of different size and shape, widely placed ochrefasciata sp. nov.

\section{- Macrobathra gentilis Meyrick}

(Figs. 1,2 \& 4-8)

Macrobathra gentilis Meyrick, 1918, Exotic Microlepidoptera, 2 : 212.

Male: Head bronzy fuscous. Labial palpi blackish, second segment ochraceous on outside; third segment marked with ochraceous streaks.

Thorax blackish. Forewing with ground colour blackish on upper surface with four markings - a broad light yellow band little away from base with squarish part adjoining costa white, two white spots on costa and another light yellow on tornus triangular in shape. Under surface blackish-fuscous except grey discal cell, both costal spots comparatively apparent. $\mathrm{R}_{3}$ closely approximated to base of $\mathrm{R}_{4}+\mathrm{R}_{5}$; $\mathrm{M}_{1}, \mathrm{M}_{2}, \mathrm{M}_{3}$ equidistant (Fig. 4). Hindwing with ground colour on upper and under surfaces brownish-fuscous, except whitish-ochraceous subhyaline area from costa to lower margin of cell in basal twothird, former bearing an expansible tuft of light brownish-ochraceous hair scales; $\mathrm{M}_{3}, \mathrm{CuA}_{1}$ closely approximated at base (Fig. 5).

Abdomen, marked with transverse whitish-ochraceous bands, much broader on under surface. Male genitalia (Fig. 6) asymmetrical; uncus absent; incurved processes of gnathos unequally sclerotized, with asymmetrical tips, forming a C-like structure; tuba analis membranous; tegumen large and broad; saccus nearly as long as rest of genitalia, more sclerotized at apex, juxta transverse band- like, bearing a strongly leaf-like process; valvae simple, blunt at tip with valva adjoining process of juxta comparatively more sclerotized. Aedeagus (Fig. 7) cylindrical; posterior half of vesica rugose, bearing a bunch of moderately long spines and a variably sclerotized plate; opening of ductus ejaculatorius lateral. Female genitalia
(Fig.8) with corpus bursae oblong; pair of closely lying parallel signa structurally similar; corpus bursae narrowing into ductus bursae without any demarcation; anterior apophyses almost half of posterior, apices of both pairs broader; papillae anales elongate, adorned with setae of varying lengths.

Alar expanse: Male: 9-10 mm; Female: $10-11 \mathrm{~mm}$.

Material examined : 1 ㅇ, $01 . v i .2000 ; 1 \hat{\jmath}$, 24.viii.2000; 1 q, $10 . \mathrm{ix} .2000 ; 1$, 12.ix.2000; 2우, 02.v.2001; 1, 15.v.2001; 1ठे, 14.vi.2001; $1 \hat{\partial}$, 12.ix.2001; 1ㅇ, 04.x.2001; 1, 30.iii.2002; 1क, 23.iv.2002; 1 \%,

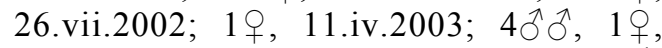
13.iv.2003; Chandigarh, INDIA. $1 \hat{\partial}$, 11.viii.2000; Sitamata Sanctuary, Rajasthan, INDIA. 10, 05.iv.2002; Kalesar (Forest Rest House), Haryana, INDIA. 1우 23.vii.2004; Subathu (Forest Guest House), 10, 25.vi.2004; Sairighat (Forest Guest House), Himachal Pradesh, INDIA. (Coll.: D. Wadhawan \& V.K.Walia) Deposited in Entomology Section, Department of Zoology, Panjab University, Chandigarh, INDIA.

Flight period: March to October.

Old distribution: $\quad$ India - Kanara and Dharwar (Karnataka) (Clarke, 1963).

Remarks: Documented body colouration and structure of male genitalia of Macrobathra gentilis Meyrick (Meyrick, 1916-1923; Clarke, 1963) was entirely in accordance with features observed in the collected and dissected specimens. All the collected 10 males and 13 females of this species from Chandigarh, Sitamata Sanctuary and Kalesar in North-West India is a new record.

\section{- Macrobathra ochrefasciata sp. nov.}

(Figs.3 \& 9-13)

Male : Head with vertex light brown; frons ochraceous. Scape of antenna light brown with cone-like blackish-fuscous patch above; flagellum black, with a linear series of sparsely placed light yellow specks. Labial palpi light yellow; third segment bearing alternate light yellow and blackish-fuscous longitudinal streaks. 

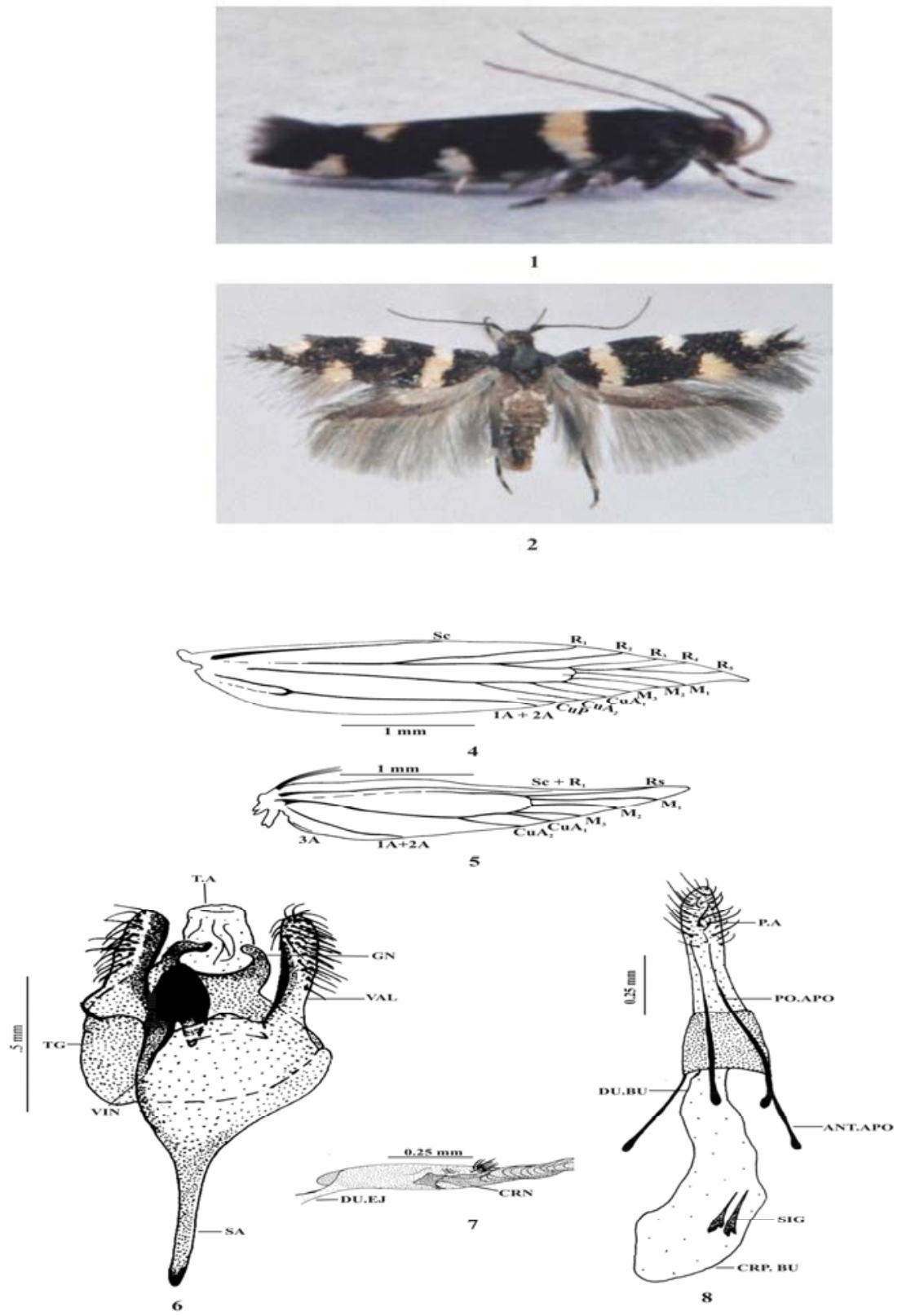

Figures 1, 2 \& 4-8: Macrobathra gentilis Meyrick; Fig. 1 - live moth (lateral view); Fig. 2 stretched (dorsal view); Fig. 4 - forewing; Fig. 5 - hindwing; Fig. 6 - male external genitalia (ventral view); Fig. 7- aedeagus; Fig. 8 - female external genitalia (dorsal view).

Thorax blackish-fuscous. Forewing with ground colour blackish-fuscous on upper surface, with various markings light yellow; a broad transverse band slightly away from base narrowing towards costa, two spots on costa and one on tornus with spot in middle of costa smallest and somewhat squarish, rest triangular; cilia along margin light brown. Under surface brownish-fuscous with lower half of band and distal costal spot conspicuously light yellow. Discal cell about three-fifth of wing length; $\mathrm{CuP}$ present (Fig. 9). Hindwing with ground colour light 
brownish-fuscous on upper and under surfaces, except subhyaline greyish in discal cell, former surface with an expansible light yellow tuft of long hair scales from near base of costa; light brown cilia along inner margin one and half of wing width. Discal cell nearly three-fifth of wing length; anterior margin of discal cell nearly obsolete, in basal three-fifth; $\mathrm{M}_{3}$ and $\mathrm{CuA}_{1}$ separate (Fig. 10). Legs light yellow with patches of blackish fuscous.

Abdomen fuscous on upper surface, with diffused greyish-white stripes, distal tip yellow; under surface alternately banded with whitish-ochraceous and brownish-fuscous. Male genitalia (Fig.11) asymmetrical; uncus absent; gnathos symmetrical, lobes straight and parallel, each margined on outside by equally long thorn-like structure; tegumen somewhat rectangular; saccus as long as rest of genitalia; transverse band of juxta expanded in middle, produced into strongly sclerotized process, latter broader in basal three-fifth, abruptly narrowed distally; valvae asymmetrical, one close to juxtal process comparatively more sclerotized, shoe-like, with conical projection pointing towards juxtal process most strongly sclerotized; other valva spindle-like in distal half, uniformly sclerotized. Aedeagus (Fig. 12) cylindrical, vesica sclerotized at tip, a part of it minutely denticulate; ductus ejaculatorius opening laterally. Female genitalia (Fig. 13) with corpus bursae somewhat globular, profusely denticulate; paired signa of different size and shape; ductus bursae longer than corpus bursae, its comparatively more sclerotized distal half possessing a pair of closely lying plates; anterior apophyses bigger than half of posterior, both pairs broadened at tips; papillae anales oblong, furnished with setae of varying lengths.

Alar expanse: Female and Male: $10-11$ $\mathrm{mm}$.

Material examined: HOLOTYPE: $\widehat{\partial}$, 24.vii.2004; Subathu (Forest Rest House), Himachal Pradesh, INDIA. PARATYPES: 1ㅇ, 23.iii.2001; 2 q , 20.vi.2001; Kalesar (Forest Rest House), Haryana, INDIA. 10ิ, 24.vii.2004; 2ð, 24.vii.2004; Subathu (Forest Rest House), Himachal Pradesh,
INDIA. (Coll.: D. Wadhawan \& V.K.Walia) Deposited in Entomology Section, Department of Zoology, Panjab University, Chandigarh, INDIA.

Flight period: March, June and July. Type locality: Subathu (Himachal Pradesh).

Etymology: Macrobathra ochrefasciata sp. nov. has been named highlighting ochraceous colouration of the frons.

Remarks: The present species resembles Macrobathra myrocoma Meyrick because of somewhat ochraceous colouration of head that is not recorded in any other so far described species from India (Meyrick, 1910, 1914a, 1915, 1916-1923, 1923-1930, 1930-1936). Like the closely allied species, forewing of new species is marked with a broad band one-fourth away from base, two spots on costa and one on inner margin between the two. However, critical examination of the wing maculation of female specimens and the genitalia clearly differentiated $M$. ochrefasciata sp. nov. from the allied species (Clarke, 1963). In contrast to three rounded spots on forewing and a thorn-like signum in the corpus bursae of $M$. myrocoma, spots are distinctly triangular and corpus bursae is adorned with a pair of unequal-sized signa in ochrefasciata sp. nov. (Meyrick, 1914a; Clarke, 1963).

\section{Abbreviations used in figures}

$1 \mathrm{~A}+2 \mathrm{~A}=$ vein representing fused first and second anal vein; $3 \mathrm{~A}=$ third anal vein; ANT.APO = anterior apophysis; $\mathrm{CRN}=$ cornuti; CRP.BU $=$ corpus bursae; $\mathrm{CuA}_{1}=$ first anterior cubital vein; $\mathrm{CuA}_{2}=$ second anterior cubital vein; $\mathrm{CuP}=$ posterior cubital vein; DU. BU = ductus bursae; DU. EJ = ductus ejaculatorius; $\mathrm{GN}=$ gnathos; JUX = juxta; $\mathrm{M}_{1}=$ first median vein; $\mathrm{M}_{2}=$ second median vein; $\mathrm{M}_{3}=$ third median vein; $\mathrm{P} . \mathrm{A}=$ papilla analis; $\mathrm{PO} . \mathrm{APO}=$ posterior apophysis; $\mathrm{R}_{1}=$ first radial vein; $\mathrm{R}_{2}=$ second radial vein; $\mathrm{R}_{3}=$ third radial vein; $\mathrm{R}_{4}=$ fourth radial vein; $\mathrm{R}_{5}=$ fifth radial vein; $\mathrm{Rs}=$ radial sector vein; $\mathrm{SA}=$ saccus; $\mathrm{Sc}+\mathrm{R}_{1}=$ fused subcosta and first radial veins; $\mathrm{Sc}=$ subcosta; $\mathrm{SIG}=$ signum; T.A = tuba analis; $\mathrm{TG}=$ tegumen; $\mathrm{VAL}=$ valva; $\mathrm{VES}=$ vesica; $\mathrm{VIN}=$ vinculum . 


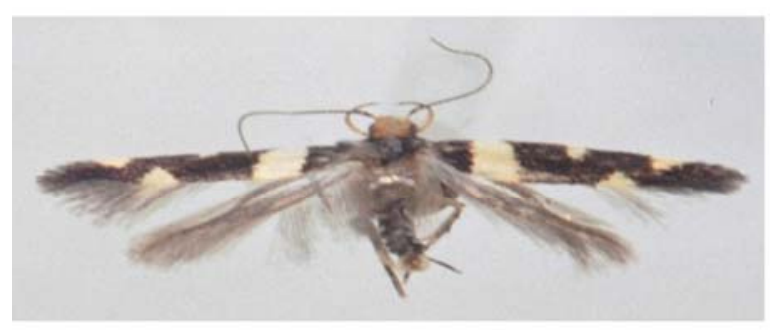

3
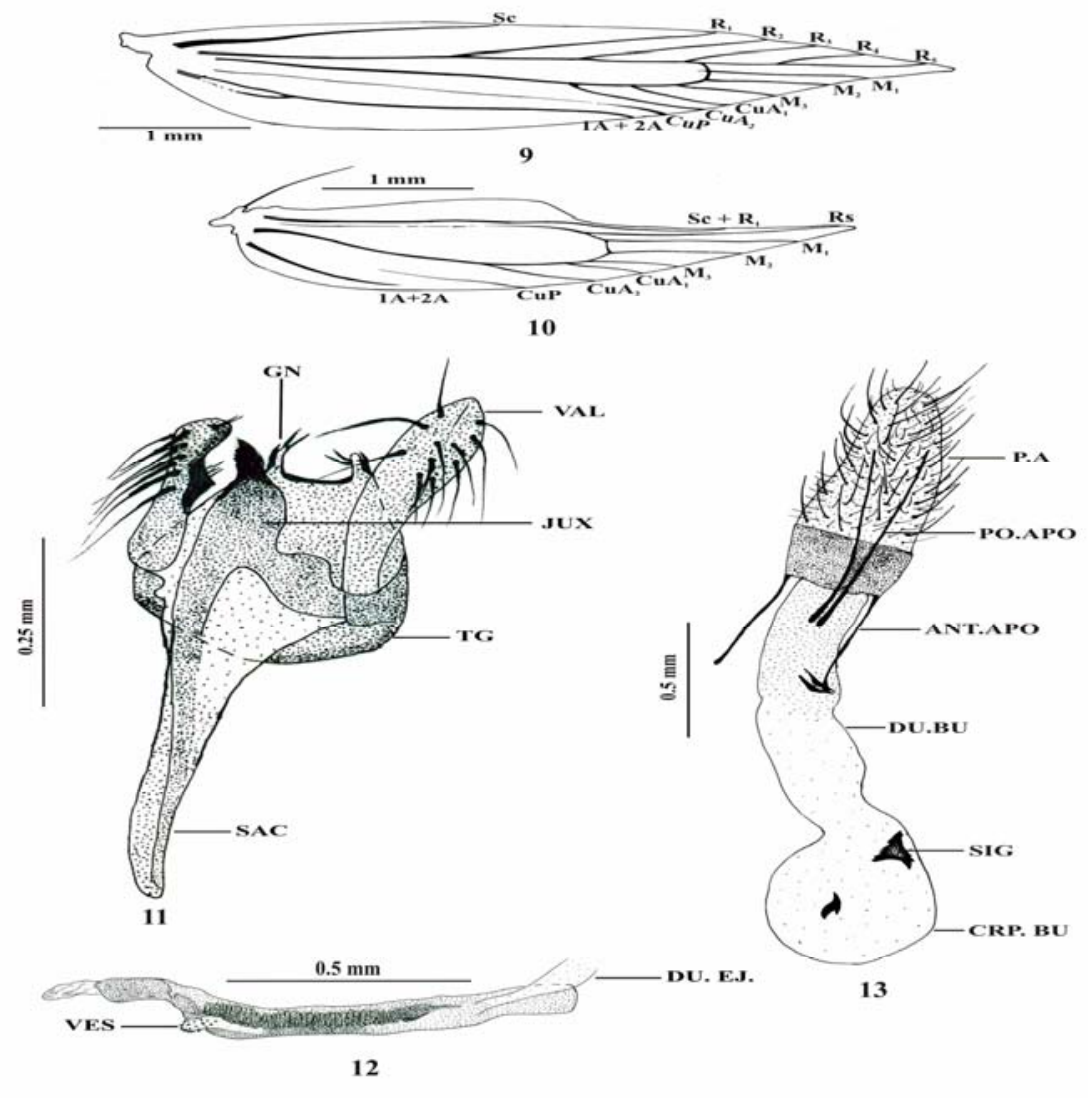

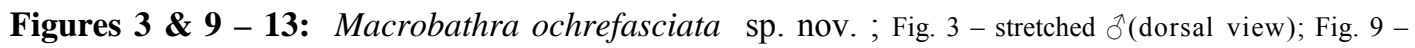
forewing; Fig. 10 - hindwing; Fig. 11 - male external genitalia (ventral view); Fig. 12 - aedeagus; Fig. 13 - female external genitalia (dorsal view).

\section{ACKNOWLEDGEMENTS}

The authors are sincerely thankful to the Ministry of Environment and Forests for sanctioning an All India Coordinated project on Taxonomy for research on Microlepidoptera (AICOPTAX) No. J22018/58/99-CSC (BC). Authors are indebted to the Forest Department in the concerned states for rendering cooperation during collection of material. We are also grateful to Prof. (Mrs.) T. Gill, Chairperson, Department of Zoology, Panjab University, Chandigarh (India) for providing necessary facilities and secretarial assistance.

\section{REFERENCES}

Clarke JFG. 1963. Catalogue of the type specimens of microlepidoptera in the 
British Museum (Natural History) described by Edward Meyrick. Vol. IV. Trustees of the Brit. Mus. (Nat. Hist.): London; 1-521.

Gaede M. 1938. Catalogue of Gelechiidae. Lepidopterorum Catalogus, 79: 630p.

Meyrick E. 1910. Descriptions of Indian microlepidoptera. J. Bombay Nat. Hist. Soc., 20: 143-168, 435-462, 706-736.

Meyrick E. 1914a. Descriptions of Indian microlepidoptera. J. Bombay Nat. Hist. Soc., 23: 18-130.

Meyrick E. 1914b. Lepidoptera : Heterocera, Family Heliodinidae. Gen. Insect., 165: 129, pl. 21.
Meyrick E. 1915. Descriptions of South American microlepidoptera. Trans. Ent. Soc. Lond., 2: 201-256.

Meyrick E. 1922. Lepidoptera : Heterocera, Family Oecophoridae. Gen. Insect.,180: $1-$ 224, pl. 1-6.

Meyrick E. 1916-1923. Exot. Microlepid. Marlborough. 2: 1-640.

Meyrick E. 1923-1930. Exot. Microlepid. Marlborough. 3: 1-640.

Meyrick E.1930-1936. Exot. Microlepid. Marlborough, 4: 1-642.

Robinson GS, Tuck KR, Schäffer M. 1994. A field guide to the smaller moths of southeast Asia. Malaysian Nature Society: Malaysia; 1-308, 32 pls. 